\title{
Analysis of Chickpea Value Chain and Determinants of Market Options Choice in Selected Districts of Southern Ethiopia
}

\author{
Tewodros Tefera ${ }^{1}$ \\ ${ }^{1}$ School of Environment, Gender and Development Studies, College of Agriculture, Hawassa University, Ethiopia \\ Correspondence: Tewodros Tefera, School of Environment, Gender and Development Studies, College of \\ Agriculture, Hawassa University, Ethiopia. E-mail: dagted@gmail.com
}

Received: February 24, 2014 Accepted: July 15, 2014 Online Published: September 15, 2014

doi:10.5539/jas.v6n10p26 URL: http://dx.doi.org/10.5539/jas.v6n10p26

\begin{abstract}
Chickpea value chain study was conducted in selected districts of the south region where CIFSRF project was operating. In total 227 respondents comprising 162 chickpea producers; 11 local assemblers; 8 rural wholesalers; 8 urban wholesalers and 38 retailers were interviewed. The study finding shows that the chickpea value chain actors are broadly classified into three viz., inputs suppliers, direct market actors and enablers. Chickpea producers sold their chickpea products to different market intermediaries and final consumers. About nine chickpea marketing channels were identified. The total amount of chickpea that was transacted through these marketing channels in 2012/13 was 9,181qts. Out of which the project site farmers supply $77 \%$ while $27 \%$ were imported from other chickpea producing areas. The study result shows that the total gross marketing margin was $45.8 \%$ with producer participation margin of $54.2 \%$. Approximately $10.2 \%$ out of a total gross marketing margin of $45.8 \%$ constitutes the total marketing charges, giving a net marketing margin of $35.5 \%$. Although this suggests an appreciable level of profits reaped by traders, volumes traded are relatively low as compared to other cereals. The market intermediaries incurred different marketing costs such as packing, processing, transportation and loading unloading. Determinants of chickpea producer participation in alternative market options were analyzed. A multinomial logit analysis results show that family size, landholding, access to market information and Income from crops was positively influences wholesale market participation as compared to farm gate. Similarly landholding, access to market information and extension services positively influence consumer market participation than farm gate while access to information and income from crops positively influences retails market participation than farm gate. On the other hand membership to cooperatives was negatively influences wholesale, retail and consumer market participation than farm gate market option. Households distance from nearest market negatively influences wholesale market participation than farm gate market option while off farm activities negatively influences retail market participation than farm gate. The study suggested that availing credit for agricultural marketing, promoting collective marketing, strengthening of extension service, provision of market information and road development improves farmers marketing margin and chickpea value chain performance.
\end{abstract}

Keywords: Chickpea, value chain, market margin, multinomial logit, chickpea marketing options

\section{Introduction}

Markets continue to be seen as the means for ensuring that smallholder producers of agricultural products are effectively integrated into the mainstream of national economies, especially in developing countries. For one thing, markets provide the opportunity for farm production to contribute to poverty reduction through the cash income realized from sales of farm produce. In turn, markets drive production as farmers strive to meet the demands of consumers and end-users in terms of quantity and quality. But their very existence, or how effectively they function, cannot be guaranteed in many developing countries. In Ethiopia, there is a certain urgency to address the real concern that, in spite of considerable investments into restructuring the sector since 1992 and directly tackle agrarian and land reform, poverty is still rife and there is the clear indication that much of this arises from farmers not being able to sell produce at a profit. Unlocking markets for this group of farmers is therefore considered a crucial developmental necessity. Research and case studies conducted in various parts of the country point to the importance of the market access to smallholders (Chilot et al., 2010).

IDRC/CDRI has committed in improving food and nutrition security in Ethiopia and engaged in Research and 
Development work for more than a decade in partnership with Hawassa University. Thus far interventions such as enhancing the soil health, promoting improved and bio-fortified varieties of pulse crops, introduction of better processing and food preparation, market and value chain development, gender, nutrition education and human capital development are the major ones. Cognizant to the importance of value chain approach to stimulate both chickpea supply and demand side Equation, attention was given to study the marketing practice and value chain of chickpea in call 3 project.

Pulse production is the major component of farming in the project sites. Haricot bean and chickpea are widely produced by the majority of farmers and playing a crucial and diverse role in the farming systems and in the diets of the community. They are ideal crops for simultaneously achieving four developmental goals in targeted areas - reducing poverty, improving human health and nutrition, cash generation and enhancing ecosystem resilience.

\section{Objectives of the Study}

This study addressed the following specific objectives: (i) identify different marketing channels and intermediaries involved therein and their roles in chickpea marketing; (ii) determine the extent of value addition in terms of marketing cost and margins in successive stages of chickpea movement; and (iii) determine factors influencing households' choice of market options.

\section{Methodology}

\subsection{Description of the Study}

The study is conducted in four districts: i) Halaba special district, ii) Damot Gale district of Wolita zone, iii) Meskan district of Guraghe zone, and iv) Soddo district of Guraghe zone. A combination of qualitative and quantitative methods was used for primary data collection. For household questionnaire survey a total sample size of 227 respondents comprising of 162 Farmers, 8 rural wholesalers, 38 retailers, 8 urban wholesalers and 11 rural assemblers took part. A single Focus Group Discussion (FGD) per kebele with mixed community group conducted. On Average 8 persons participated in the FGD.

\subsection{Data Source and Type}

This study used two kinds of data sources: (1). Interview of chickpea producers and intermediaries such as local assemblers, rural wholesalers, urban wholesalers and retailers using structured questionnaire; (2). Focus group discussion with farmers. The survey instruments were designed to explore the chickpea production, marketing, product follow and distribution, marketing costs and margins. To complement the structured survey focus group discussion was conducted with relevant chickpea value chain actors. Moreover personal observation and secondary data collection were made.

\subsection{Sampling Procedure and Methods of Data Collection}

A multistage sampling procedure was adopted for this study. After the four districts had been selected, a stratified sampling frame of chickpea producers and non producers were prepared. For the present study participants from producers' stratum were randomly selected until the required sample size was achieved. On the other had chickpea traders such as local assemblers, rural wholesalers, urban wholesalers and retailers were sampled at village and district towns by employing snow ball sampling techniques. Because of the limited number of traders the sample exhaustively contained almost all chickpea traders in the study area. In total 162 chickpea producers; 11 local assemblers; 8 rural wholesalers; 8 urban wholesalers and 38 retailers were interviewed making a total number of 227 respondents for the study.

Primary data were collected using four enumerators recruited from each district office of agriculture in the study districts. Before the actual data collection went on one day training and orientation was given on the content and approach of survey administration. These enumerators were closely and frequently supervised by the researcher and the required data from the producers were gathered using a pretested interview schedule. For the traders, a spate questionnaire was design and administered. The research design employed was a cross sectional one with the aim of identifying market actors, market channels, marketing cost, margins and factors influencing the choice of market channel by chickpea farmers.

\subsection{Data Analysis}

Primary data was entered in the SPSS spread sheet and cleaned for irregularities. The cleaned data was summarized into descriptive format in terms of frequencies, percentages and central tendencies. STATA software was used to analysis the Multinomial Logistic Model for the identification of factors influencing marketing options. Based on the primary data, the average prices at different market levels were estimated, after which 
average price margins for different market intermediaries were computed.

\subsection{Estimation of Marketing Costs and Marketing Margins}

Different types of marketing costs (including transport, packing, processing, loading unloading etc.,) relating to transaction of chickpea for producers and each traders (local assemblers, rural wholesalers, urban wholesalers and retailers) were collected per quintal basis.

The term marketing margin is commonly refers to the difference between producer and consumer prices of an equivalent quantity and quality of a commodity (Tomek \& Robinson, 1990). However, it may also describe price differences between other points in the marketing chains. It is a price charged for providing a mix of marketing services such as assembling, transportation, handling, packing, processing, storage etc. plus profit. Marketing margins for the various chickpea traders were estimated using the following formulas.

$$
\begin{aligned}
& \mathrm{TGMM}=\frac{\text { Retailing Price }- \text { Farm gate Price }}{\text { Retailing/Consumer Price }} \times 100 \\
& \mathrm{GMM}_{\mathrm{RA}}=\frac{\text { Rural Assembler Price }- \text { Farm gate Price }}{\text { Retailing/Consumer Price }} \times 100 \\
& \mathrm{GMM}_{\mathrm{RWS}}=\frac{\text { Rural wholesalers }- \text { Rural Assembler Price }}{\text { Retailing/Consumer Price }} \times 100 \\
& \mathrm{GMM}_{\mathrm{UWS}}=\frac{\text { Rural wholesalers }- \text { Rural Assembler Price }}{\text { Retailing/Consumer Price }} \times 100 \\
& \mathrm{GMM}_{\mathrm{R}}=\frac{\text { Retailing Price }- \text { Urban Wholesalers }}{\text { Retailing/Consumer Price }} \\
& \mathrm{NMM}=\mathrm{TGMM}-\mathrm{TMC} \\
& \mathrm{GMM}=100
\end{aligned}
$$

Where

TGMM is Total Gross Marketing margin;

$\mathrm{GMM}_{\mathrm{RA}}$ is the percentage of the total gross marketing margin received by rural assemblers;

$\mathrm{GMM}_{\mathrm{RWS}}$ is the percentage of the total gross marketing margin received by rural wholesalers;

$\mathrm{GMM}_{\mathrm{UwS}}$ is the percentage of the total gross marketing margin received by urban wholesalers;

$\mathrm{GMM}_{\mathrm{R}}$ is the percentage of the total gross marketing margin received by retailers;

$\mathrm{GMM}_{\mathrm{P}}$ is the producers gross marketing margin;

TMC is the total marketing cost;

NMM is the net marketing margin.

\subsection{Econometric Model}

The primary goal of the econometric model used in this study is to explain the effects of the independent variables $X_{i}$ (i.e. farmers household, production and marketing characteristics) on the probability of choosing among the various market channels exist in our study: rural assemblers, rural wholesalers, urban wholesalers and retailers. The outcome is nominal because the categories are assumed to be unordered. Therefore the most appropriate model to estimate farmers' decision to sell in one of these four different market channels is a strategy choice model, specifically a Multinomial Logistic Model (MNL). This model was used because it is the standard method for estimating unordered, multi category dependent variables. It also assumes independence across the choices, that is, it does not allow correlation or substitution between them (Wooldridge, 2008).

In this model each household makes only one choice from a group of available strategies, and this discussion is based on a number of exogenous factors. Those factors include household level and area-specific variables. For the $\mathrm{i}^{\text {th }}$ farmer faced with $\mathrm{j}$ choices, suppose that the utility of choice $\mathrm{j}$ is: 


$$
\mathrm{U}_{\mathrm{ij}}=\mathrm{Z}_{\mathrm{ij}} \beta+\varepsilon_{\mathrm{ij}}
$$

If farmer makes choice $\mathrm{j}$ in particular, then we assume that $\mathrm{U}_{\mathrm{ij}}$ is the maximum among the $\mathrm{j}$ utilities. Hence the standard model will be driven by the probability that choice $\mathrm{j}$ is made which is,

$$
\text { Probability }\left(\mathrm{U}_{\mathrm{ij}}>\mathrm{U}_{\mathrm{ik}}\right) \text { for all other } \mathrm{K} \# \mathrm{j}
$$

Assuming that $\mathrm{Yi}$ represents the choice taken, then with $\mathrm{j}$ disturbances being distributed identically and independently the multinomial logit model adopted. The multinomial logit is actually an extension of the binary logit model, having more than two values for the dependent variable. Let $\left(\mathrm{p}_{0}, \mathrm{p}_{1} \ldots \mathrm{p}_{\mathrm{m}}\right)$ be the probabilities of $\mathrm{m}+1$ alternatives of choice. The probability of an individual $\mathrm{i}$ to choose the alternative $\mathrm{j}$ is given by:

$$
\operatorname{Prob}(Y i=j)=\frac{\exp \left(x_{i} b_{i}\right)}{1+\sum_{j=1}^{m} \exp \left(x_{i} b_{i}\right)} \text {, where } \mathrm{j}=0,1 \ldots \mathrm{m}
$$

Where $x_{i}$ is the vector of the independent variables associated to the individual $i$, and $b_{j}$ is the vector of parameters associated to the alternative $\mathrm{j}$.

Following Equation 3, the generalization of the logit model for the multinomial case is made by taking different parameters $b_{j}$ depending on the alternatives of choice, such that the independent variables $x_{i}$ remain constants depending on the products. Still, there is another possibility: the McFadden's conditional logit model which considers a constant vector of parameters $b$ and allows the independent variables xij to depend on the alternatives (McFadden 1974, 1980). The probability of an individual $\mathrm{i}$ to choose the product $\mathrm{j}$ is given by:

$$
p_{i j}=P\left(y_{i}=j\right)=\frac{\exp \left(x_{i j} b\right)}{\sum_{k=1}^{m} \exp \left(x_{i k} b\right)}=\frac{\exp \left(x_{i j}^{*} b\right)}{1+\sum_{k=1}^{m} \exp \left(x_{i k}^{*} b\right)}, \mathrm{j}=1,2, \ldots \mathrm{m}
$$

Where $\mathrm{x}_{\mathrm{ij}}{ }^{*}=\mathrm{x}_{\mathrm{ij}}-\mathrm{x}_{\mathrm{i} 0}$.

Based on Equation 4, according to Greene (2002) and Mugisha et al. (2004) and the fact that farmer's participation in different market options is categorized into alternatives, using those who participated in the village market option (selling to rural assemblers) as the base alternative. The other alternatives include selling to wholesalers (rural and urban wholesalers based in rural and district towns), retailers and consumers options. The ratio of the probabilities, hence estimated as follows:

$$
\frac{P\left(y_{i}=j\right)}{P\left(y_{i}=l\right)}=\frac{\exp \left(x_{i j}^{*} b\right)}{\sum_{k=1}^{m} \exp \left(x_{i k}^{*} b\right)}=\frac{\exp \left(x_{i j} b\right)}{\sum_{k=1}^{m} \exp \left(x_{i k} b\right)} \quad \forall j, l=1,2, \ldots m
$$

Which, as in the case of the multinomial logit is independent of the other alternatives of choice i.e. selling at farm gate, wholesale, retailers or consumer market.

The marginal effects are obtained from the multinomial logit regression results by the following Equation:

$$
\frac{\partial p_{j i}}{\partial x_{j i}}=p_{j i}\left(\beta_{i}-\sum p_{k i} \beta_{k}\right)
$$

Where, $\beta$ and $\mathrm{P}$ represents the parameter and likelihood, respectively, of the choices. Marginal likelihood gives better indications and represents changes in dependent variable for a given change in a particular explanatory variable whereas holding the other explanatory variables at their sample means. The models are estimated under maximum likelihood procedure which yield consistent, asymptotically normal and efficient estimate.

\section{Result and Discussion}

\subsection{Chickpea Value Chain Actors and Major Functions}

Inputs supply: the major seed suppliers in the study areas were HwU CIFSRF project, traders, informal farmer to farmer seed exchange, Debre Zeit Agricultural Research Centre. WoA was the major actor identified in supply of fertilizer, insecticide and herbicide while MFI supply short term credit.

Chickpea grain supply: The chickpea value chain major function from intermediaries' point of view was analyzed. The result indicates that the major sources of chickpea supply are farmers. However, the degree of dependence on farmers for chickpea grain supply varies from one to another. Local assemblers fully met their chickpea supply requirements from farmers. Rural wholesalers depend on farmers for $50 \%$ of their chickpea requirement while retailers and urban wholesalers obtained 34 and 25\% of their chickpea grain from farmers respectively. Intra and inter trade is common among chickpea intermediaries and chickpea flow depending on price signals, marketing cost and concentration of customers. There was a statistical difference in chickpea grain suppliers among chickpea intermediaries.

Credit supply: wholesalers are the major source of credit in the chickpea trade. Out of the total 22 traders who 
took credit in 2012/13 production season, $77.2 \%$ of them were met their credit need from wholesalers. The Microfinance institutions (MFI) supply credit for $18.2 \%$ of the chickpea traders while relatives supply for $4.6 \%$.

Source of information: retailers are the major source of information. To limited extent retailers, brokers, wholesalers and mass media were identified as source information in the chickpea market. The retailers' greater access to information might be due to their frequent contact with chickpea actors and consumers. The role of mass media as source information was less important.

Chickpea buyers: the major buyers of chickpea are consumers. Wholesalers and retailers are also the secondary buyers of chickpea to resale back to consumers and other needy buyers. There is a statistically significant difference at $1 \%$ level in terms of chickpea buyers.

Table 1. Chickpea value chain actors and their major roles

\begin{tabular}{|c|c|c|c|c|c|}
\hline \multirow{2}{*}{$\begin{array}{l}\text { Chickpea actors and } \\
\text { major functions }\end{array}$} & \multicolumn{4}{|c|}{ Traders } & \multirow{2}{*}{ Totals } \\
\hline & Rural wholesalers & Retailers & Urban wholesalers & Local assemblers & \\
\hline \multicolumn{6}{|l|}{ Chickpea suppliers } \\
\hline Farmers & $4(50)$ & $13(34)$ & $2(25)$ & $11(100)$ & $30(55.3)$ \\
\hline Retailers & $0(0)$ & $6(16)$ & $0(0)$ & $0(0)$ & $6(9.23)$ \\
\hline Brokers & $0(0)$ & $0(0)$ & $1(12.5)$ & $0(0)$ & $1(1.54)$ \\
\hline Other wholesalers & $4(50)$ & $18(47)$ & $5(62.5)$ & $0(0)$ & $27(41.5)$ \\
\hline Pearson chi $2=31.66$ & & & & & $\operatorname{Pr}=0.007$ \\
\hline \multicolumn{6}{|l|}{ Credit suppliers } \\
\hline IMF & $30(100)$ & $0(0)$ & $0(0)$ & $1(50)$ & $4(18.20)$ \\
\hline Wholesalers & $0(0)$ & $12(100)$ & $5(100)$ & $0(0)$ & $17(77.26)$ \\
\hline Relatives & $0(0)$ & $0(0)$ & $0(0)$ & $1(50)$ & $1(4.55)$ \\
\hline Pearson chi $2=22.00$ & & & & & $\operatorname{Pr}=0.001$ \\
\hline \multicolumn{6}{|l|}{ Source of information } \\
\hline Retailers & $5(62.6)$ & $19(67.8)$ & $4(50)$ & $11(100)$ & $39(70.9)$ \\
\hline Brokers & $0(0)$ & $1(3.57)$ & $3(37.5)$ & $0(0)$ & $4(7.27)$ \\
\hline Wholesalers & $3(37.5)$ & $6(21.4)$ & $1(12.5)$ & $0(0)$ & $10(18.2)$ \\
\hline Mass media & $0(0)$ & $1(3.6)$ & $0(0)$ & $0(0)$ & $1(1.8)$ \\
\hline Pearson chi $2=16.56$ & & & & & $\operatorname{Pr}=0.167$ \\
\hline \multicolumn{6}{|l|}{ Chickpea buyers } \\
\hline Consumers & $2(25)$ & $36(97.3)$ & $2(25)$ & $5(45.5)$ & $45(69.2)$ \\
\hline Wholesalers & $0(0)$ & $0(0)$ & $0(0)$ & $6(54.5)$ & $6(9.2)$ \\
\hline Retailers & $6(75)$ & $1(0)$ & $6(75)$ & $0(0)$ & $13(20)$ \\
\hline Pearson chi $2=81.96$ & & & & & $\operatorname{Pr}=0.000$ \\
\hline
\end{tabular}

Figures in parenthesis are percentage. 


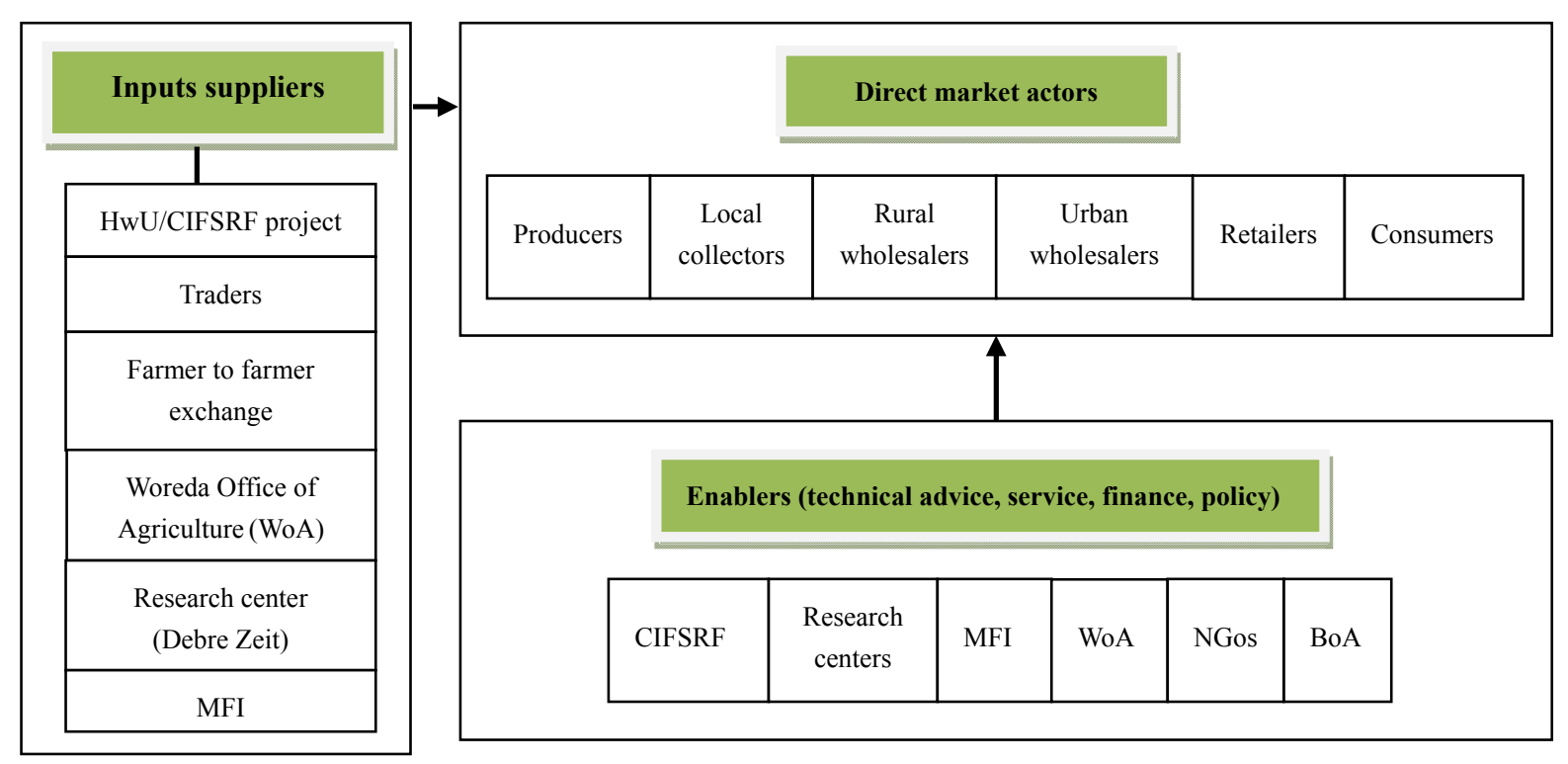

Figure 1. Chickpea value chain actors

The chickpea value chain actors: The chickpea value chain actors are broadly classified into three viz., inputs suppliers direct market actors and enablers. The inputs suppliers mainly deliver inputs such as seeds, fertilizers, finance and pesticide. The major actors identified in the inputs supply functions are CIFSRF project, traders, farmers, Debre Zeit Agricultural Research centers, MFI, and woreda office of agriculture. The direct market actors are those involved the chickpea trade and they dictate the flow of chickpea in time and space. These include producers, local collectors, wholesalers, retailers and consumers. The enablers are the inputs suppliers are coincide most of the times as most of the input suppliers also involved in technical advice, service provision and policy formulation and implementation of the same.

\subsection{Marketing Channels of Chickpea}

Chickpea is an important cash crop and it passes through the hands of many intermediaries. Based on the direction of flow and volume of chickpea transacted, nine marketing channels were identified. The channel starts from the producers (farmers) and ends in the terminal market passing through a number of marketing actors along the chain. According to producers survey which involves 162 respondents in the four study districts in the year 2012/13 about 318 quintals of chickpea was marketed. However, the trader survey shows that 6708 qt of chickpea is purchased from farmers in the study areas while 2473 quintal of chickpea was imported outside the project area. Hence, the total amount of chickpea that was transacted 2012/13 in the project districts was found to be 9,181 qts. In order to quantify the volume of chickpea handled by each marketing actor along the marketing chain, the total purchased amount was obtained from the producer and trader surveys. The trader survey shade light that the study areas are not chickpea secured and $27 \%$ of the chickpea demand was met through import from other regions of the country. Urban wholesalers played a critical role in filling this deficit.

The study identified nine chickpea marketing channels. The amount of chickpea transacted in these market channels was different and out of the nine, four market channels were found to be dominant in terms of chickpea volume of transaction. Marketing channel 1 starts from producers and ends with final consumer. In this market channel about 350 qt chickpea (3.8\%) was supplied. Channel 2 involves producers, retailers and consumers. It was found to be the least dominant one in terms of volume of chickpea supply. In this market channel only $0.8 \%$ of the total chickpea was supplied. Marketing channel 3 was the dominant one, about $36 \%$ of the chickpea was supplied in this channel. The participants of this market channel include producers, rural assemblers, urban wholesalers and consumers. Channel 4, 5, 6 and 7 supply $3.5 \%, 8 \%, 2.3 \%$ and $6.4 \%$ of chickpea respectively. Marketing channel 8 and channel 9 were dominant as they accounted for the supply of $12 \%$ and $27 \%$ of the chickpea respectively. Market channel 8 comprises of market actors such as producers, urban wholesalers, retailers and consumers where as market channel 9 include centrally located wholesalers in the capital city Addis Ababa and Debre Zeit, local urban wholesalers and consumers. 


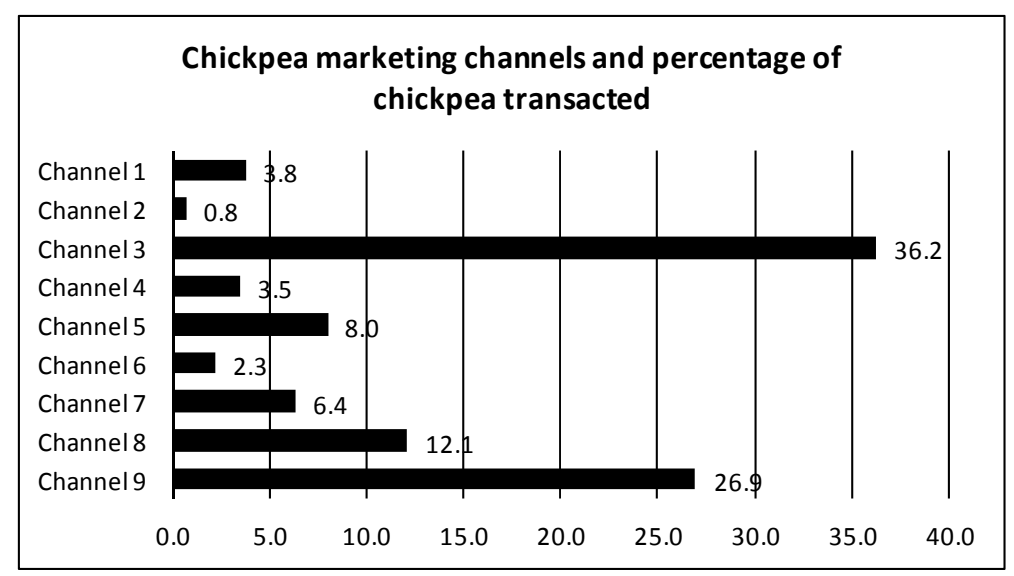

Figure 2. Chickpea marketing channels

The identified channels were:

Channel 1: Producers $\longrightarrow$ Consumers (350qt)

Channel 2: Producers $\longrightarrow$ Retailers $\longrightarrow$ Consumers (70qt)

Channel 3: Producers $\longrightarrow$ Rural Assemblers $\longrightarrow$ Consumers (3322 qt)

Channel 4: Producers $\longrightarrow$ Rural Assemblers $\longrightarrow$ Urban wholesalers $\longrightarrow$ Consumers (325qt)

Channel 5: Producers $\longrightarrow$ Rural wholesalers $\longrightarrow$ Consumers (735qt)

Channel 6: Producers $\longrightarrow$ Rural wholesalers $\longrightarrow$ Retailers $\longrightarrow$ Consumers (208qt)

Channel 7: Producers $\longrightarrow$ Urban wholesalers $\longrightarrow$ Consumers (586qt)

Channel 8: Producers $\longrightarrow$ Urban wholesalers $\longrightarrow$ Retailers $\longrightarrow$ Consumers (1112qt)

Channel 9: Central Wholesalers $\longrightarrow$ Urban wholesalers $\longrightarrow$ Consumers (2473qt) 


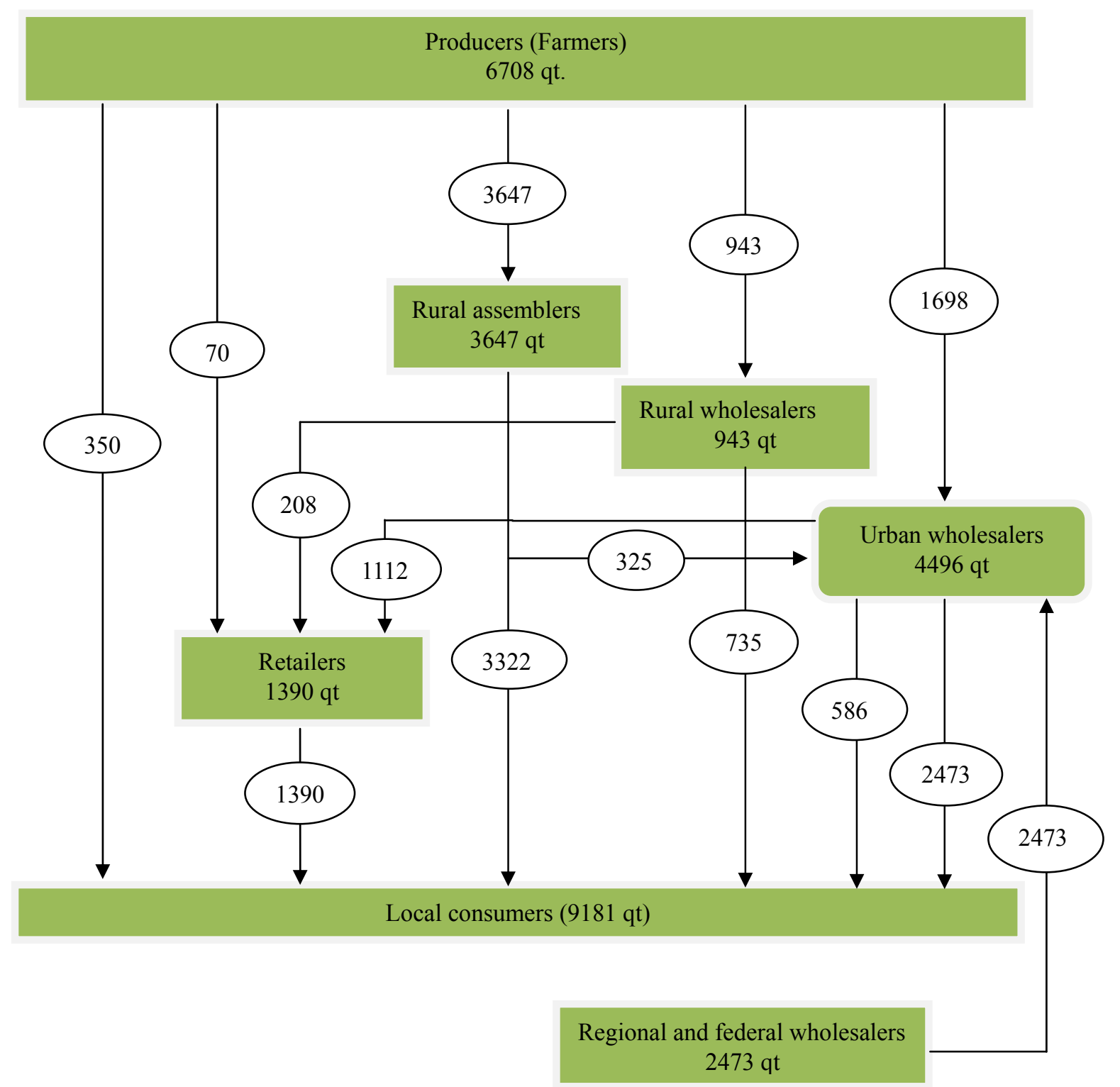

Figure 3. Chickpea marketing channels; the figures represent volume of chickpea passing in the different market channels

\subsection{Marketing Margin of Chickpea}

Results of the marketing margins analysis showed a total gross marketing margin of $45.8 \%$ with producer participation margin of $54.2 \%$. The gross marketing margin for chickpea is rather on the high side as compared to that of hot pepper which is about 29\% (Amare \& Dawit, 2013). Approximately 10.2\% out of a total gross marketing margin of $45.8 \%$ constitutes the total marketing charges, giving a net marketing margin of $35.5 \%$. Although this suggests an appreciable level of abnormal profits reaped by traders, volumes traded are relatively low as compared to other cereals. 
Table 2. Chickpea marketing margin

\begin{tabular}{lll}
\hline Price at various level of chain actors & Birr/qt & Gross marketing margins \\
\hline Average farm gate price & 663.30 & - \\
Average rural assemblers price & 752.20 & - \\
Average rural wholesalers price & 895.00 & - \\
Average urban wholesalers price & 1048.45 & - \\
Average retailing price & 1224.15 & - \\
TGMM & - & $45.8 \%$ \\
$\mathrm{GMM}_{\mathrm{RA}}$ & - & $7.3 \%$ \\
$\mathrm{GMM}_{\mathrm{RWS}}$ & - & $11.6 \%$ \\
$\mathrm{GMM}_{\mathrm{UWS}}$ & - & $12.5 \%$ \\
$\mathrm{GMM}_{\mathrm{R}}$ & - & $14.4 \%$ \\
$\mathrm{GMM}_{\mathrm{P}}$ & - & $54.2 \%$ \\
\hline
\end{tabular}

Again disaggregating total net marketing margins by the key traders along the distribution chain indicate that retailers absorb a higher proportion of the total which compensates for the low volumes traded (13.2\%). However, there is a fair representation of profit allocation among rural and urban wholesalers leaving very little to rural assemblers $(4.2 \%)$.

Table 3. Chickpea marketing costs

\begin{tabular}{ccccc}
\hline \multirow{2}{*}{ Marketing cost } & \multicolumn{4}{c}{ Districts } \\
\cline { 2 - 5 } & Rural wholesalers & Retailers & Urban wholesalers & Local assemblers \\
\hline Packing & 2.00 & - & 4.00 & 10.00 \\
Processing & - & 6.44 & - & - \\
Transport & 18.20 & 5.60 & 29.25 & 19.10 \\
Loading unloading & 5.60 & 0.57 & 3.18 & 2.18 \\
Total marketing cost & 25.8 & 12.04 & 36.43 & 32.28 \\
Total as \% of retail price & 2.5 & 1.1 & 3.5 & 3.1 \\
GMM (\%) & 11.6 & 14.3 & 12.5 & 7.3 \\
NMM\% & 9.1 & 13.2 & 9.0 & 4.2 \\
\hline
\end{tabular}

\subsection{Market Participation}

In subsistence production system producers have played dual roles of producing and consuming. And in such system what is produced may not be sold or partly sold to market. According to the study findings the market participation level for chickpea producers ranges between 69\% in Halaba and 100\% in Meskan. This indicates chickpea is a cash crop and contribute much to the household cash generation. In all the study areas the overwhelming majority of respondents confirm that their income from chickpea is increasing. Despite the cash generation form chickpea has shown increase there is statistical difference among the districts at $5 \%$ level. 
Table 4. Producers' participation in chickpea market

\begin{tabular}{ccccccc}
\hline \multirow{2}{*}{ Chickpea marketing } & \multicolumn{5}{c}{ District } & \multirow{2}{*}{ Chi2 } \\
\cline { 2 - 5 } & Halaba & Damot Gal & Sodo & Meskan & \\
\cline { 1 - 4 } Market participation & 69 & 78 & 95 & 100 & $18.74^{* * * *}$ \\
Trends of income obtained from chickpea & 59 & 67 & 56 & \\
Increasing & 51 & 11 & 14 & 22 & \multirow{2}{*}{ Percentage } \\
Decreasing & 3 & 20 & 12 & 6 & \\
Same & 13 & 9 & 7 & 16 & \\
Difficult to tell & 33 & &
\end{tabular}

**, *** indicates that chickpea market participation and trends in income obtained from chickpea are significantly different from zero among districts at the 5 and 1 percent level, respectively.

\subsection{Determinants of Market Option Participation}

For this analysis some of the market options (rural and urban wholesalers) are merged and rural assembler market option is renamed village market. Accordingly the market option is categorized into four namely village market, wholesale market, retailers and consumers. Out of the four options wholesale and retailers market are dominant while village market and consumer market are limited in terms of market outlet options.

Table 5. Chickpea market option

\begin{tabular}{cccc}
\hline Market option & Freq. & Percent & Cum. \\
\hline Village market & 11 & 7.75 & 7.75 \\
Wholesale market $(\mathrm{R}+\mathrm{U})$ & 93 & 65.49 & 73.24 \\
Retailers & 26 & 18.31 & 91.55 \\
Consumers & 12 & 8.45 & 100.00 \\
Total & 142 & 100.00 & \\
\hline
\end{tabular}

\section{Variables Used in Multinomial Logit Regression:}

Membership in cooperatives: the majority of respondents who sold their chickpea products at the farm gate, directly to consumers and retailers market options were member of cooperative whereas $73 \%$ of respondents who sold their chickpea to wholesalers market option were nonmembers of cooperatives. The observed difference in the choice of market options is statistically significant at $1 \%$ level.

Access to market information: the majority of the respondents were affirmed their access to market information. From those who sold their chickpea to wholesales, retails and consumers the overwhelming majority (greater than $50 \%$ ) had access to market information while the majority of the respondents who sale their chickpea at farm gate lack market information. The difference in market option choice is statistically influenced by market access and the observed difference was statistically significant at $1 \%$ level.

Access to extension service: the majority of the respondents who sold to farm gate (81.82\%), wholesale (89.25\%), retail $(88 \%)$ and consumer $(75 \%)$ market option had access to extension services. Access to extension service influence on market option choice was not statistically significant.

Off-farm participation: only $9 \%$ of those who sold to farm gate market option participated in off-farm activities while $29 \%$ of respondents each who sold to wholesales and retails participated in off-farm activities. The differences in off-farm activities participation were not statistically influencing market options.

Access to credit: the majority of respondents who had access to credit participated in retails (56\%) and consumer (58\%) markets. Among the respondents who sold their chickpea at farm gate and wholesales market options only $18 \%$ and $38 \%$ of them had access to credit. The difference in credit access to credit was statistically influencing market options choice at $10 \%$ level of significance. 
Table 6. Descriptive statistics of variables used in the model (discreet variables)

\begin{tabular}{|c|c|c|c|c|c|}
\hline \multirow{2}{*}{ Categorical variables } & \multicolumn{4}{|c|}{ Market option } & \multirow{2}{*}{ Chi2 } \\
\hline & Farm gate & Wholesale & Retailers & Consumer & \\
\hline \multicolumn{6}{|l|}{ Membership in coops } \\
\hline - Yes & $9(81.82)$ & $25(26.88)$ & $14(53.85)$ & $7(58.33)$ & $18.55^{* * *}$ \\
\hline \multicolumn{6}{|c|}{ Access to market information } \\
\hline - Yes & $5(45.45)$ & $80(86.02)$ & $19(73.08)$ & $6(50)$ & $15.82 * * *$ \\
\hline \multicolumn{6}{|c|}{ Access to extension service } \\
\hline - Yes & $9(81.82)$ & $83(89.25)$ & $22(88)$ & $9(75)$ & $2.25 \mathrm{~ns}$ \\
\hline \multicolumn{6}{|c|}{ Participate in off-farm activities } \\
\hline - Yes & $1(9.09)$ & $27(29.03)$ & $7(29.17)$ & $3(25)$ & $2.05 \mathrm{~ns}$ \\
\hline \multicolumn{6}{|l|}{ Access to credit } \\
\hline - Yes & $2(18.18)$ & $36(38.71)$ & $14(56)$ & $7(58.33)$ & $6.30^{*}$ \\
\hline
\end{tabular}

*, and *** Imply level of significance at 10 and $1 \%$ respectively.

Years of schooling in formal education: those who sold their chickpea at farm gate had 4.3 years of formal education while those who sold in wholesales, retails and consumer market had 5.8, 6.45 and 4.8 years of formal education respectively. The finding indicates that education statistically influence choice of market option at 10 $\%$ level.

Family size: the finding show that households having large average family size preferred to sale for consumers and retail market options. However, family size was not statistically influence the choice of market options.

Total landholding: respondents own the largest average land holding sold their chickpea at farm gate while those own the smallest average land holding sold to consumers market. However, landholding was not found to be statistically influence the choice of market options.

Distance from home to nearest market: households sold to the farm gate market option was found on average 11 $\mathrm{km}$ away from the nearest market while those who sold for wholesales, retails and consumers market option located on average 9, 8, and $10.9 \mathrm{~km}$ away from home. The observed difference in distance from the nearest market influence the choice of market option and it was found to be statistically significant at $10 \%$ level.

Income from crops: households who got large income from crops prefer to sale for consumers and retails market options. On the other hand those households who generate small average income from crops sold their chickpea to wholesales and farm gate markets. Average crops income influence market options and the result was statistically significant at $10 \%$ level.

Production costs: households incurred higher production costs sold their chickpea for wholesales and consumers markets. Producers and wholesalers also interlined in the credit market as the wholesalers supply credit to producers as the later expected to deliver their produces to them. The preference to consumer market is motivated by higher price. However the observed difference was not statistically significant.

Marketing cost: households who sold at farm gate market on average incurred less marketing costs compared to those sold to wholesales (11.8), retails (14.5) and consumers (15.4). The difference however, was not statistically significant. 
Table 7. Descriptive statistics of continuous variables

\begin{tabular}{cccccc}
\hline \multirow{2}{*}{ Continuous variables } & \multicolumn{5}{c}{ Market option } \\
\cline { 2 - 5 } & Farm gates & Wholesales & Retails & Consumers & \\
\hline Education (average years of schooling) & 4.3 & 5.8 & 6.45 & 4.8 & $2.17^{*}$ \\
Family size & 7.66 & 7.58 & 8.65 & 9.27 & $1.53 \mathrm{~ns}$ \\
Total land holding (ha) & 2.20 & 1.82 & 1.86 & 1.74 & $0.5 \mathrm{~ns}$ \\
Distance from home to nearest market (km) & 11.1 & 9.03 & 8.25 & 10.9 & $2.19^{*}$ \\
Income from crops & $7,571.50$ & $9,267.56$ & $14,494.67$ & $39,686.00$ & $2.79 *$ \\
Production cost (Birr) & 208.1 & 437.6 & 196.21 & 382.75 & $1.05 \mathrm{~ns}$ \\
Marketing cost (Birr) & 5.25 & 11.77 & 14.46 & 15.42 & $0.66 \mathrm{~ns}$ \\
\hline
\end{tabular}

*, and *** Imply level of significance at 10 and $1 \%$ respectively.

\subsection{Factors Affecting the Choice of Chickpea Marketing Options}

In this section, results from the estimation of the multinomial logit model are presented. Discussion of the results focuses on the three comparisons within the model: the comparisons of mass wholesales, retails, and consumers market options to the farm gate. In a next section, the three comparisons within the model are evaluated in terms of individual variables that were found to be significant.

In terms of goodness of fit, the model had acceptable measures. The likelihood ratio chi2 was 79.41 and the pseudo-R2 measures were 34.79 . These measures were statistically significant at less than $1 \%$ level. In order to develop broader understanding of how producers' characteristics, their access to resources and services are related to marketing options choice the 0.10 level was chosen to indentify significant coefficient estimates

Family size: according to the results, family size was positively influences wholesale market participation and the result was significant at $10 \%$ level. As the family size of the households changes by one, the probability of participating in the wholesale market than farm gate increases by $1.7 \%$ implying that the chickpea producers will sell more chickpea in the wholesale market as compared to the farm gate market. The finding agree with the prior expectation that large family size implies better labour endowment so that households are in a position to travel to get wholesalers in the district or nearby town markets.

Cooperative membership: The finding reveals that, membership to cooperatives was statistically significant and negatively influences wholesale, retail and consumer market participation respectively. As the membership status of the households' changes from not member to member, the probability of participating in the wholesale market than farm gate reduces by $31.1 \%$ implying that the households will sell fewer amounts of chickpea in the wholesale market as compared to the farm gate market. Similarly cooperative member's participation in retail and consumer markets reduces by 2.6 and $2.1 \%$ as compared to farm gate markets. This was inconsistent with the prior expectation. It was assumed that cooperatives members are price conscious and they sale their chickpea to markets which pay higher price.

Total landholding: the results indicate that the household's ownership of total landholding positively influences wholesale and consumer market participation. As the landholding size increases by one hectare, the probability of participating in wholesale and consumer than farm gate increases by 0.7 and $0.2 \%$ respectively. This is consistent with Machethe et al. (2008) who find that larger land sizes raise the probability of market participation for farmers since land is a critical production asset having a direct bearing on production of a marketable surplus, ceteris paribus. This implies that those with large parcels of land are likely to participate more in markets especially in wholesale and consumers markets as they have scale advantage to reduce costs to take products to distance market.

Distance from home to nearest market: the study finding shows that, households distance from nearest market was significant at $10 \%$ level and negatively influences wholesale market participation. As the distance of the household from nearby market increased by one kilometer, the probability of participating in the wholesale market compared to farm gate market reduces by $4.4 \%$ implying that the households will sell fewer chickpea in the wholesale market as compared to the farm gate market. This result concurs to the prior expectation, as household's location further from market places they prefer to sell their produce at farm gate.

Access to market information: Access to market information positively influences wholesale, retail and consumer 
markets participation such that, a change in a farmer's status from no access to market information to access increases the probability of wholesale, retail and consumer markets participation than farm gate by $33.8,1.7$ and $3 \%$ respectively. This implies that access to information will make the farmer participate more in the wholesale, retail and consumer than the farm gate market option. Market information enable the farmer to improve their decision making on what to produce and to whom to sell which in turn increases his/her marketed surplus and market participation (Lapar et al., 2002; Shepherd, A., 1997).

Crops income: income from crops influences wholesale and retail markets participation positively and significantly. An increase in the yearly income by one Ethiopian birr increases the probability of participating in the wholesale and retail market than farm gate by 1.7 and $0.2 \%$ respectively. The increase in cash resources will make the households invest more in chickpea production and marketing activities resulting to more surplus driving them to sell to wholesale which is a larger market compared to farm gate.

Participation in off farm activities: the results show that participation in off farm activities negatively influences retail market participation. As the farmer involved in off farm activities the time he/she has to spare for marketing of agricultural activities and to produce marketable surplus is less, hence this decreases the probability of participating in retail market than farm gate increases by $13.3 \%$.

Access to extension service: it positively influences consumer market participation such that, a change in a farmer's status from no access to extension to access increases the probability of consumer market participation than farm gate increased by $29.3 \%$. This implies that extension will make the farmer participate more in the consumer than the farm gate market option. Extension services enable the farmer to improve his production methods hence leading to more output which in turn increases his/her marketed surplus hence market participation (Lapar et al., 2002), especially in terminal markets which provide lucrative price.

Table 8. Determinates of chickpea producer choice of market options

\begin{tabular}{|c|c|c|c|c|}
\hline Market participation options & Coef. (Std. Err.) & $\mathrm{z}$ & $\mathrm{P}>|\mathrm{z}|$ & Marginal effects \\
\hline \multicolumn{5}{|c|}{ Wholesales option } \\
\hline Years of education & $-0.20(0.265)$ & -0.77 & 0.442 & 0.010 \\
\hline Family size & $0.474(0.24)$ & 1.92 & $0.055^{*}$ & 0.017 \\
\hline Co-ops membership & $-7.57(3.64)$ & -2.08 & $0.038 * *$ & -0.311 \\
\hline Total landholding & $0.15(0.073)$ & 1.97 & $0.049 * *$ & 0.017 \\
\hline Distance from home to nearest market & $-0.49(0.25)$ & -1.94 & $0.052 *$ & -0.044 \\
\hline Access to market information & $7.39(3.28)$ & 2.25 & $0.024 * *$ & 0.338 \\
\hline Income from crops & $0.047(0.026)$ & 1.76 & $0.078^{*}$ & 0.001 \\
\hline Marketing cost & $-0.134(0.094)$ & -1.42 & 0.156 & -0.008 \\
\hline Access to extension service & $-0.485(1.68)$ & -0.28 & 0.776 & -0.050 \\
\hline Participation in off farm activities & $-1.63(1.58)$ & -1.03 & 0.302 & 0.061 \\
\hline Access credit & $1.16(1.65)$ & 0.7 & 0.484 & 0.087 \\
\hline cons & $-4.60(7.67)$ & -0.6 & 0.548 & \\
\hline \multicolumn{5}{|c|}{ Retail market option } \\
\hline Years of education & $-0.267(0.27)$ & -0.99 & 0.324 & -0.005 \\
\hline Family size & $0.389(0.25)$ & 1.55 & 0.12 & 0.005 \\
\hline Co-ops membership & $-6.43(3.65)$ & -1.76 & $0.079 *$ & -0.026 \\
\hline Total landholding & $0.11(0.075)$ & 1.4 & 0.161 & -0.003 \\
\hline Distance from home to nearest market & $-0.215(0.26)$ & -0.83 & 0.409 & 0.022 \\
\hline Access to market information & $6.24(3.31)$ & 1.88 & $0.06^{*}$ & 0.017 \\
\hline Income from crops & $0.057(0.03)$ & 2.1 & $0.036^{* *}$ & 0.002 \\
\hline Marketing cost & $-0.12(0.096)$ & -1.24 & 0.216 & -0.002 \\
\hline Access to extension service & $-0.686(1.73)$ & -0.39 & 0.693 & -0.054 \\
\hline Participation in off farm activities & $-2.67(1.63)$ & -1.64 & $0.10^{*}$ & -0.133 \\
\hline Access credit & $0.498(1.72)$ & 0.29 & 0.773 & -0.060 \\
\hline _cons & $1.22(8.0)$ & 0.15 & 0.879 & \\
\hline
\end{tabular}




\begin{tabular}{ccccc}
\hline & Consumers market option & & \\
Years of education & $-0.486(0.296)$ & -1.64 & $0.10^{*}$ & -0.016 \\
Family size & $0.528(0.261)$ & 2.02 & $0.043^{* *}$ & 0.008 \\
Co-ops membership & $-6.66(3.708)$ & -1.8 & $0.073^{*}$ & -0.021 \\
Total landholding & $0.152(0.080)$ & 1.9 & $0.057^{*}$ & 0.002 \\
Distance from home to nearest market & $-0.234(0.275)$ & -0.85 & 0.395 & -0.007 \\
Access to market information & $5.593(3.361)$ & 1.66 & $0.096^{*}$ & 0.030 \\
Income from crops & $0.033(0.028)$ & 1.18 & 0.239 & -0.001 \\
Marketing cost & $-0.028(0.103)$ & -0.27 & 0.789 & 0.005 \\
Access to extension service & $1.19(0.53)$ & 2.24 & $0.023^{* *}$ & 0.293 \\
Participation in off farm activities & $-1.92(1.725)$ & -1.11 & 0.266 & -0.013 \\
Access credit & $1.09(1.682)$ & 0.65 & 0.516 & 0.015 \\
_cons & $-9.54(8.47)$ & -1.13 & 0.26 & \\
\hline
\end{tabular}

*, and *** Imply level of significance at 10 and $1 \%$ respectively.

Village market is the base outcome; Number of observation $=133$; LR chi2 $=79.41$; Log likelihood $=-74.52$; prob. $>\chi^{2}=0.000$; pseudo $\mathrm{R} 2=34.79$.

\section{Conclusion}

Chickpea production is the major component of farming system in the project sites. It contributes significantly to household consumption and cash income generation. In this study focus has been given on exploring the value chain of chickpea in selected potential chickpea producing districts and identification of factors influencing market outlet options.

The study identified three categories of value actors viz., inputs suppliers direct market actors and enablers. The inputs suppliers mainly deliver inputs such as seeds, fertilizers, finance and pesticide. The major identified actors in the inputs supply domain include CIFSRF project, traders, farmers, Debre Zeit Agricultural Research centres, MFI, and woreda office of agriculture. The direct market actors are those involved the chickpea trade and they dictate the flow of chickpea in time and space. The major value chain actors in this category include producers, local assemblers, rural wholesalers, urban wholesalers, retailers and consumers. About nine chickpea marketing channels were identified. The total amount of chickpea that was transacted through these marketing channels in $2012 / 13$ was 9,181 qts. Off which the project site farmers supply $77 \%$ while $27 \%$ were imported from other chickpea producing areas.

Chickpea producers incurred in kind and cash expenses for hired labour, fertilizers, seed and pesticides. In addition producers expended marketing cost such as sale tax, transportation, loading unloading and packing charges. While the majority of respondents was reported their access to extension, limited number of them had access to credit and participated in off farm activities. Involvement of some intermediaries seems to be redundant whose presence just adds a cost to the consumer and a loss to the smallholder farmers by reducing their price share. Moreover, the superfluous involvement of intermediaries keeps chickpea producers and markets separated not allowing them to be market responsive.

The study result shows that the total gross marketing margin was $45.8 \%$ with producer participation margin of $54.2 \%$. Approximately $10.2 \%$ out of a total gross marketing margin of $45.8 \%$ constitutes the total marketing charges, giving a net marketing margin of $35.5 \%$. Although this suggests an appreciable level of abnormal profits reaped by traders, volumes traded are relatively low as compared to other cereals. The market intermediaries incurred different marketing costs such as packing, processing, transportation and loading unloading.

Determinants of participation in alternative market option were analyzed. The multinomial logit analysis results show that family size, landholding, access to market information and Income from crops was positively influences wholesale market participation as compared to farm gate. Similarly landholding, access to market information and extension services positively influence consumer market participation than farm gate while access to information and income from crops positively influences retails market participation than farm gate. On the other hand membership to cooperatives was negatively influences wholesale, retail and consumer market participation than farm gate market option. Households distance from nearest market negatively influences wholesale market participation than farm gate market option while off farm activities negatively influences retail 
market participation than farm gate.

Policy Implications:

1. The most common market option for majority of the farmers is the wholesale market because of its role in interlocked credit market and relatively better price it offers.

2. Access to market information, extension service, and credit enables farmers to participate in market options which secure them higher price for their chickpea produce

3. Households' resource endowment such as labour, income from crops and landholding size also raises households' likelihoods to participate in wholesale, retailers and consumers market options.

4. Infrastructure development also ensure better benefit for markets as distance from market outlets is a major constraint for households to participate in markets that ensure higher price.

\section{Acknowledgements}

The authors gratefully acknowledge the DFATD /IDRC for funding this study. The author has also benefited from discussions with, and the support of, Dr. Sheleme Beyene, Dr. Carol Henery and Dr. Atul Nayyar.

\section{References}

Amare, H., \& Dawit, A. (2013). Marketing channel and margin analysis: A case study of red pepper marketing at Jabitehinan District in Northwestern Ethiopia. International Journal of Agricultural Economics and Extension, 1(6), 31-40.

Chilot, Y., Shahidur, R., Befekadu, B., \& Solomon, L. (2010). Pulses Value Chain Potential in Ethiopia: Constraints and opportunities for enhancing exports. International Food Policy Research Institute (IFPRI).

Greene, W. H. (2002). Econometric Analysis (5th ed.). Pearson Education Inc., New Jersey.

Lapar, M. L., Holloway, G., \& Ehui, S. (2002). Policy options promoting market participation of smallholder livestock producers: A case study of the Philippines. Socio-economic and Policy Research Working Paper 47. ILRI, Nairobi.

Machethe, C., Jagwe, J., \& Ouma, E. (2008). Transaction costs and smallholder farmers' participation in banana markets in the Great Lakes Region. Department of Agricultural Economics, Extension and Rural Development, University of Pretoria.

McFadden, D. (1980). Econometric Models of Probabilistic Choice Among Products. Journal of Business, 53, 513-529. http://dx.doi.org/10.1086/296093

Mugisha J, Mbowa, S., \& Kasibante, F. (2004). Determinants of use of Information and Communication Technologies by Agribusiness Firms in Uganda. East Afr. J. Rural Dev., 20, 377-7103.

Shepherd, A. (1997). Market Information Services: Theory and Practice. FAO (Food and Agriculture Organization), Rome.

Studenmund, A. H. (1992). Using Econometrics. Apract.cal Guide. New York. Harper Collins U.S Bureau of Census. Country Business Patterns. Economics Letter, 38, 31-36.

Tomek, W. G., \& Robinson, K. L. (1990). Agricultural Product Prices (3rd ed., pp. 107-8(360)). Cornell University Press, New York.

Wooldrige, J. M. (2008). Introductory Econometrics: A Modern Approach (4th ed.). J. W. Calhoun: CENGAGE Learning.

\section{Copyrights}

Copyright for this article is retained by the author(s), with first publication rights granted to the journal.

This is an open-access article distributed under the terms and conditions of the Creative Commons Attribution license (http://creativecommons.org/licenses/by/3.0/). 